Mongolian Geoscientist

Original article

\title{
HYDROGEOCHEMICAL IMPLICATIONS FROM IDER RIVER IN NORTHERN MONGOLIA
}

\author{
Alexander Orkhonselenge ${ }^{1^{*}}$, Amgalan-Erdene Nyamjantsan ${ }^{2}$ \\ ${ }^{1}$ Laboratory of Geochemistry and Geomorphology, School of Arts and Sciences, National University of Mongolia. Ulaanbaatar 14201. Mongolia \\ ${ }^{2}$ Mongolian National Recycling Association. Ulaanbaatar 14200, Mongolia. \\ *Corresponding author. Email: rkhnslng@num.edu.mn
}

ARTICLE INFO

Article history:

Received 30 May 2018

Accepted 26 December 2018

\begin{abstract}
This study presents the hydrogeochemical implications resulted from Ider River, one of headwaters of Selenge River in northern Mongolia which is a main headwater of Lake Baikal in southeastern Russia, being included in a drainage basin of the North Arctic Ocean. Surface water and groundwater were collected and estimated with hydrogeochemical analyses of major ionic compositions in order to determine water quality in the catchment of Ider River in northern Mongolia. Result shows that the downstream of Ider River is more polluted than upstream of Ider River and Khunjil River, an inflow of the Ider River. Surface water of Ider River and groundwater in the catchment of the Ider River are comparable with their anions and cations. Ider River is highly enriched with an anion of $\mathrm{Cl}^{-}$in 2-3 times, cations of $\mathrm{Na}^{+}+\mathrm{K}^{+}$in 2-3 times and $\mathrm{NH}_{4}{ }^{+}$in 0.5-1.0 times than those in groundwater in the catchment of Ider River. The hydrogeochemical results show that the surface water of Ider River is mainly polluted by solid wastes along its valley. More investigations with detail geochemical analyses are needed from the large rivers comprising surface water resource in Mongolia to review the hydrological evolution in Mongolia and Central Asia in the late Holocene.
\end{abstract}

Keywords: hydrology, water quality, runoff, groundwater, Northern Mongolia

\section{INTRODUCTION}

Surface water and groundwater are important components of the terrestrial hydrology and major water resources in semi-arid regions such as Mongolia in Central Asia. Water sources are particularly crucial for natural and managed ecosystems in areas where summer aridity would otherwise be a major limiting factor. This is a major concern in a region that depends so heavily on glacier melting to sustain water supplies for agriculture and other ecosystem services in summer months (Orkhonselenge and Harbor, 2018). Groundwater is a very significant water source used for irrigation and drinking purposes in the karst region, and therefore understanding the hydrogeochemistry of karst water is extremely important (Wu et al., 2009). Water resources in Mongolia play a vital role in

(C) The Author(s). 2018 Open access This article is distributed under the terms of the Creative Commons Attribution 4.0 International License (https://creativecommons.org/licenses/by/4.0/), which permits unrestricted use, distribution, and reproduction in any medium, provided you give appropriate credit to the original author(s) and source, provide a link to the Creative Commons license, and indicate if changes were made. 
regional ecological, social and economic development in Central Asia. The water bodies in Central Asia have been largely changed by water shortage and pollutants (Karthe, 2018). As regards the water resources, their geochemical characteristics are modulated by climate change, having a large impact on regional developments, through alteration of water temperature. However, in regions with relatively limited water resources anthropogenic impacts of water pollution are particularly severe and generate a serious problem. There has been a lack of work linking surface water and groundwater geochemical fluctuations and their effects by human activities. The purpose of this paper is to determine water pollution of Ider River caused by human activity and to provide a hydrogeochemical implication based on such a connection for the catchment of Ider River in northern Mongolia.

Hydrogeochemical implication from Ider River and assessment of its pollution level are essential to estimate hydrological evolution of watersheds in northern Mongolia. Determining changes in geochemical components of runoff and groundwater in response to climate change is thus an important component of understanding the context for sustainable water health in Mongolia and Central Asia. In recent years, large rivers in Mongolia are impacted by climate change and polluted by human activities such as mining, tourism and solid wastes. Among the main factors solid wastes provided by human activity are widely spread in urban areas.

Ider River is one of three headwaters of Selenge River feeding Lake Baikal, the deepest freshwater lake in the world (Fig. 1). Ider River plays an important role to feed these large fluvial systems in the basin of the North Arctic Ocean and transports sediments and pollutants through its drainage basin. Ider River is a good example of these rivers in which valleys solid wastes are overloaded by settlements and tourists and pollute the environmental components including soil, vegetation and air in their basins. Hydrogeochemical estimation has not been analytically conducted yet in the catchment of the Ider River although hydrogeological survey in the catchment of the Ider River is completed. This study aims to provide the complex geochemical implication in the catchment of Ider River.

In 1950-1960s, hydrologist Kuznetsov conducted hydrological survey in Mongolia including morphometry and water regime of

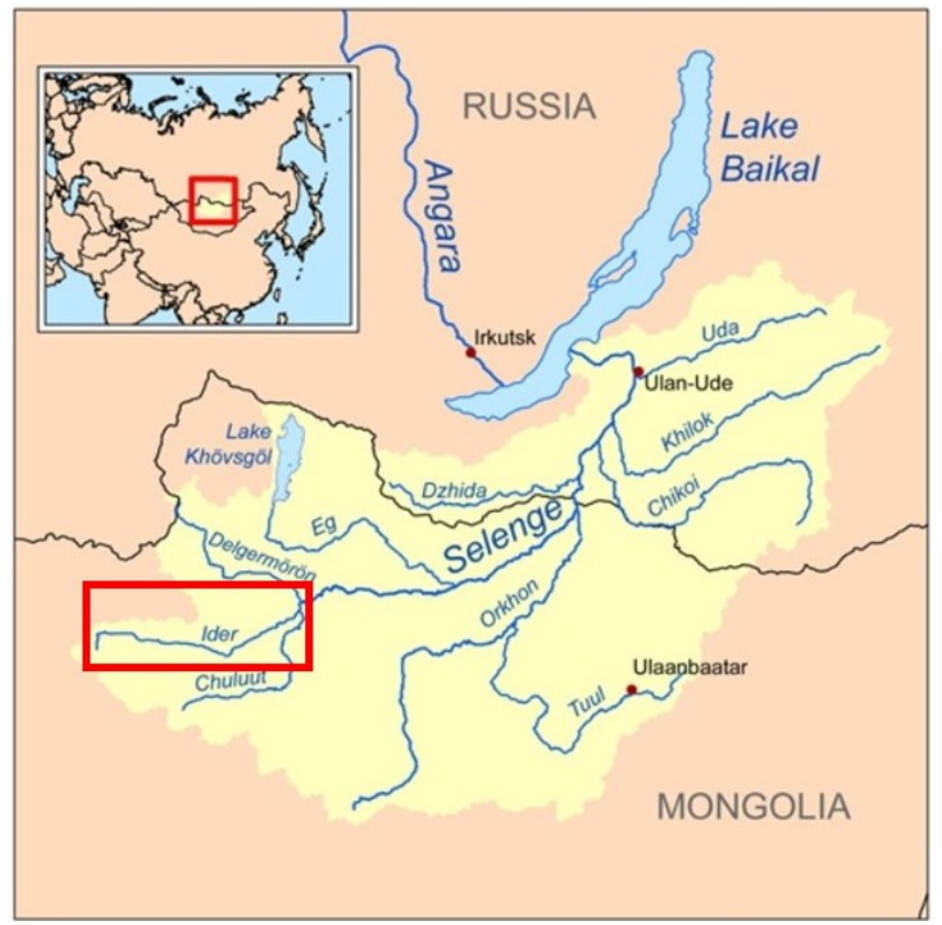

Figure 1. Geographical location of Ider River. 
rivers, and origins, morphometry and water regime of lakes (Sanjmyatav, 2007). Murzaev gave physico-geographical feedback of Ider River including water regime, water level, and development of its valley (Tsegmid, 1969). Natsag studied rivers, including Ider River, in a basin of Selenge River. Davaa (2015) synthesized surface water of Mongolia with their water regime and resource. Recently, Mongolian Water Forum has initiated water management in the catchment of Ider River.

Since 1990s investigation of solid waste began in Mongolia. In 2004, the JICA International Association studied accurately solid wastes in settlement areas of Mongolia in a frame of plan for a master program of solid waste in Ulaanbaatar (Bolorchimeg, 2013). In 2004, the Ministry of Nature and Environment promoted a model to classify the solid wastes (Ministry of Nature and Environment, 2004). AmgalanErdene (2014) developed the first model on how to manage solid wastes in rural areas in case of Jargalant soum, Khuvsgul aimag.

Here, we consider the hydrological relationship between surface water and groundwater based on hydrogeochemical estimation in the catchment of Ider River in northern Mongolia (Fig. 1). This study contributes to provide the complex hydrogeochemical implication in valley of the Ider River. This study on hydrogeochemical estimation in Ider River highlights significant point to provide ecological evaluations along the valley of the Ider River in northern Mongolia, and the basins of Selenge River and Lake Baikal in Central Asia.

\section{GEOGRAPHIC SETTING}

Ider River consisting of Shiree and Gyalgar Rivers (Davaa, 2015) is included in a basin of the North Arctic Ocean (Fig.1). Ider River drains through a valley between the Bulnai (2619 $\mathrm{m})$ and Tarvagatai $(3227 \mathrm{~m})$ Mountain Ranges, heading from the northern slope of Mt. Otgontenger $(4021 \mathrm{~m})$ of the Khangai Mountain Range, and joins the Delger and Bugsei Rivers. Ider River extends $452 \mathrm{~km}$ in length and occupies an area of 24,555 $\mathrm{km}^{2}$ (Tsegmid, 1969). According to Davaa (2015), it extents $466 \mathrm{~km}$ in length and comprises an area of $44,420 \mathrm{~km}^{2}$. A valley of Ider River is morphometrically developed well. Ider River is fed by more than 30 rivers such as Chuluut, Khojuul, Zart, Tsetsuukh and Khunjil Rivers draining from the Tarvagatai Mountain Range. A flow rate of Ider River is $7.2-10.8 \mathrm{~km} / \mathrm{h}$ and reaches $2.0-2.5 \mathrm{~km} / \mathrm{h}$ in its downstream (Davaa, 2015). Its prevailing rate is $1.5-2.0 \mathrm{~m} / \mathrm{s}$ (Dashdeleg, 1970); and $5.3 \mathrm{~m}^{3} / \mathrm{s}$ in Ider soum, $17.3 \mathrm{~m}^{3} / \mathrm{s}$ in Tosontsengel soum, and $33.9 \mathrm{~m}^{3} / \mathrm{s}$ in Galt soum (Davaa, 2015). Channel of Ider

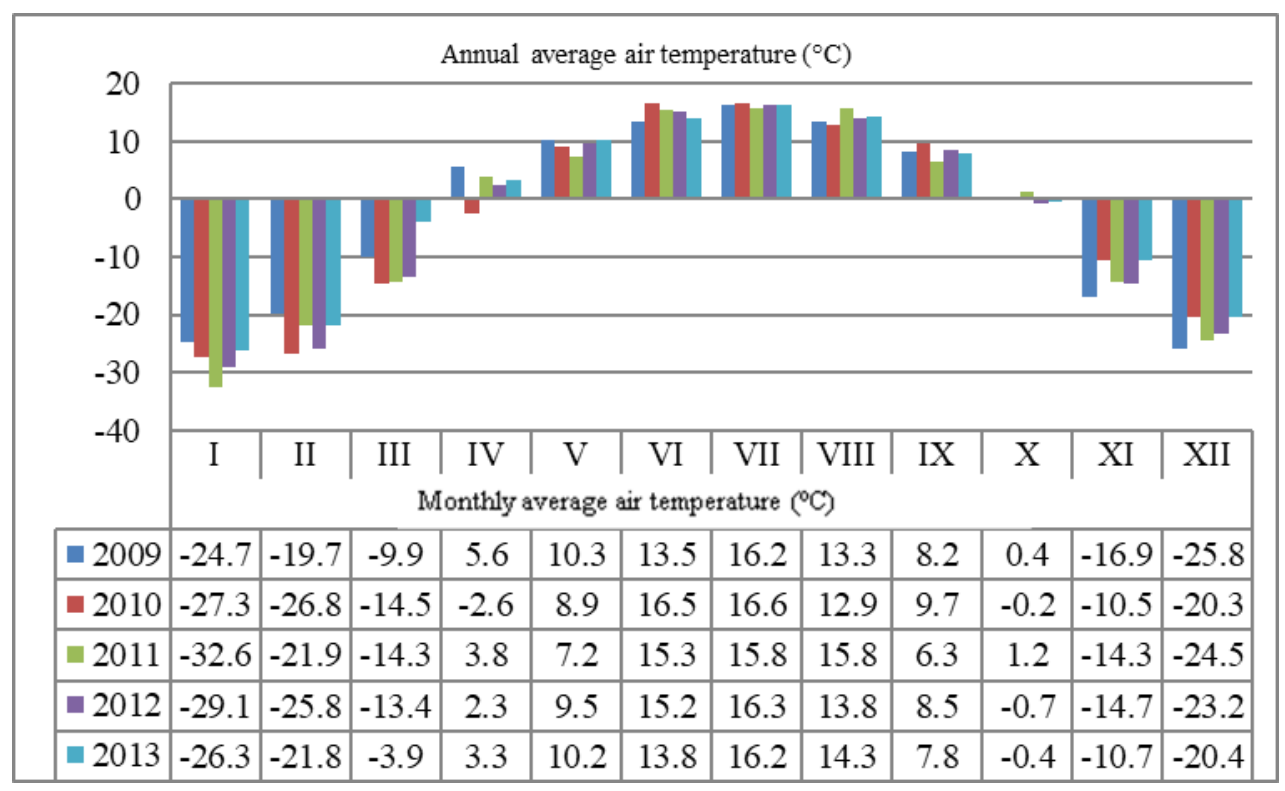

Figure 2. Monthly average air temperature at Jargalant meteorological station 
River meanly lies at $1588 \mathrm{~m}$ a.s.l. and is $10-15$ $\mathrm{m}$ wide and $0.7-2.0 \mathrm{~m}$ deep, and $80-100 \mathrm{~m}$ wide and $3.0-3.5 \mathrm{~m}$ deep at the upstream and downstream, respectively. Water $\mathrm{pH}$ of Ider River is 6.2-7.0 and contains ions of hydrocarbonate and calcium (Tsegmid, 1969). Geologically, Ider metamorphic formation consists of shale and gneiss in the early Proterozoic paleostructure of Baidrag containing dark-grey metamorphic rocks and light limes (Mitrophanov et al, 1981). It includes layers of gneiss, granite-gneiss, amphibolite, shale, magmatite, lime and quarsite.

Climatic consition is characterized with a harsh continental climatic system with longer cold winter and shorter moisture summer. Daily average air temperature is more than $10^{\circ} \mathrm{C}$ ) National Atlas of Mongolia, 2009). Annual minimum and maximum air temperatures are $45^{\circ} \mathrm{C}$ in December and January and $30^{\circ} \mathrm{C}$ in July,

Table 1. Precipitation at Jargalant meteorological station

\begin{tabular}{|c|c|c|c|c|c|c|c|c|c|c|c|c|}
\hline & \multicolumn{10}{|c|}{ Monthly average precipitation (mm) } \\
\cline { 2 - 15 } Year & I & II & III & IV & V & VI & VII & VIII & IX & X & XI & XII \\
\hline 2009 & 1.2 & 2 & 7.8 & 2.1 & 25.3 & 14 & 92.5 & 58 & 3.2 & 8.4 & 11.1 & 7.9 \\
\hline 2010 & 8.5 & 3.4 & 3.5 & 2.4 & 27.6 & 48.5 & 86.1 & 87.4 & 5.8 & 10.9 & 4.3 & 1.6 \\
\hline 2011 & 0.9 & 3.2 & 1.7 & 4.6 & 3.2 & 65.9 & 30.7 & 17.5 & 12.9 & 5.7 & 8.1 & 2.3 \\
\hline 2012 & 1 & 0 & 2.3 & 13 & 5.8 & 29.9 & 40.3 & 46 & 2.2 & 2.9 & 3.6 & 1.4 \\
\hline 2013 & 2 & 1.8 & 0.9 & 10.5 & 9.5 & 62.5 & 37.2 & 64.7 & 14.2 & 6.7 & 4.6 & 1 \\
\hline
\end{tabular}

respectively (Fig. 2). 60-70\% of total precipitation occurs in June to August (Table 1). In winter snow thickness is $5-30 \mathrm{~cm}$. Annual rainfall is approximately $300 \mathrm{~mm}$ (Jargalant Meteorological Station, 2009-2013).

\section{METHODS}

Water samplings of Ider River were taken from 2100-2700 $\mathrm{m}$ a.s.1 (N48 $35^{\prime}$ 00.23" E99 ${ }^{\circ} 20^{\prime}$ 59.96". Totally, six water samplings of Ider River and groundwater in its valley were obtained during a field work conducted in

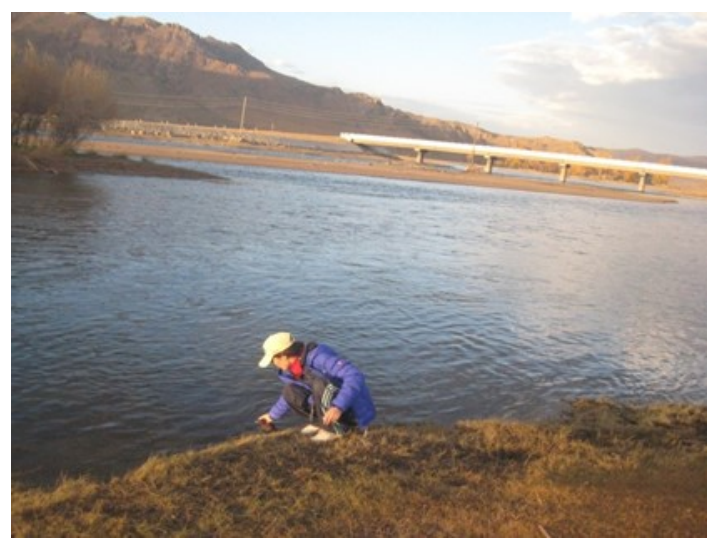

September, 2013 (Figs. 3, 4) and were hydrogeochemically analyzed for hardness, electric conductivity, oxidation and ions at Laboratory of Hydrology, Institute of Geoecology, Mongolian Academy of Sciences (MAS).

\section{RESULTS}

Hydrogeochemical composition is an intricate system depending on geographical position, bedrock, soil, vegetation and human impact. Most settlements and industrialisation take a

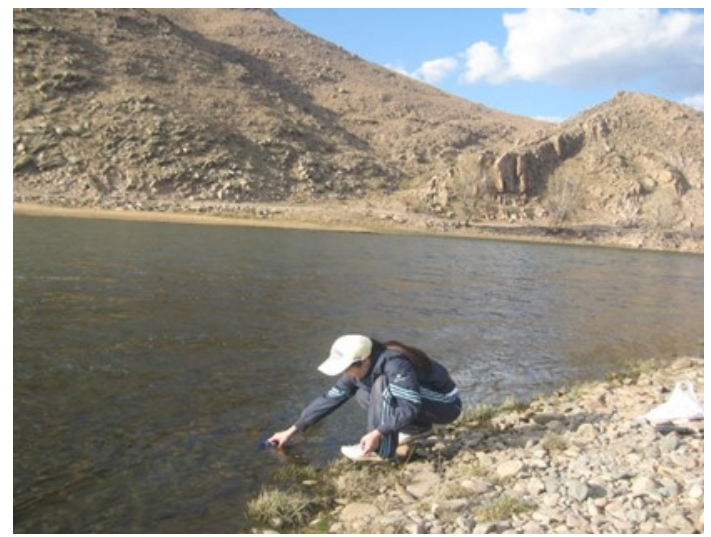

Figure 3. Upstream (right) and downstream (left) of Ider River. Photo by A.Orkhonselenge. 09.20.2013 

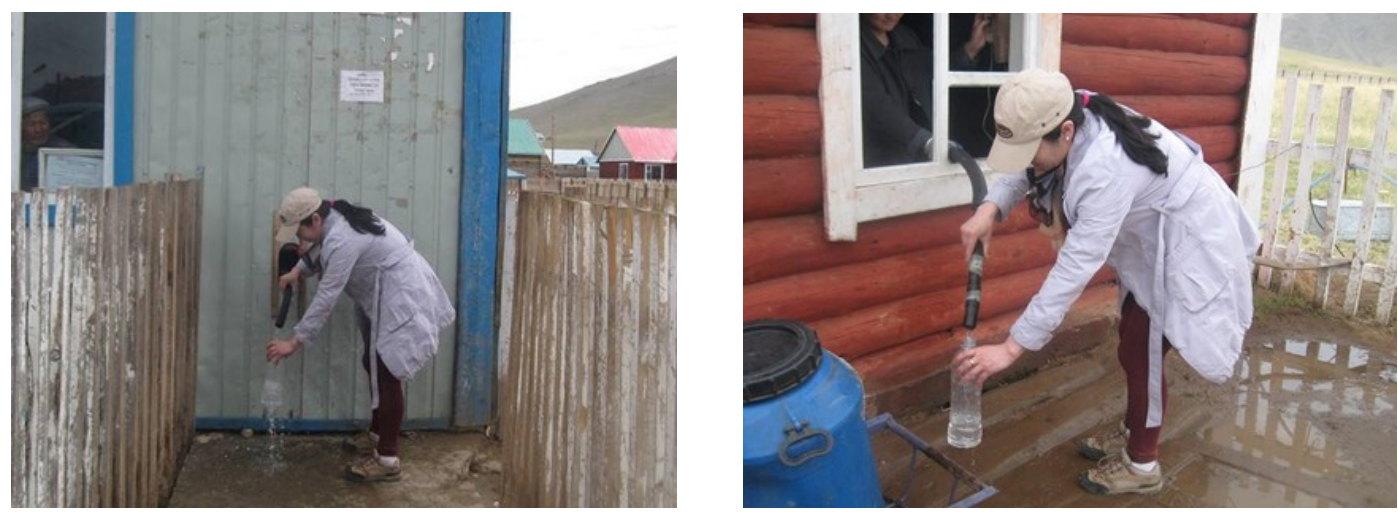

Figure 4. Groundwater sampling in school (right) and center of Jargalant soum (left)

place in valleys of large rivers where they impact on.

Upstream of Ider River is characterized as hydrocarbonate type with total anions and cations of $173.1 \mathrm{mg} / \mathrm{dm}^{3}$, hardness of $1.7 \mathrm{mg}$ - eqv $/ \mathrm{dm}^{3}, \mathrm{pH}$ of 7.97 , oxidation of $2.1 \mathrm{mg} / \mathrm{dm}^{3}$ and electric conductivity of $187 \mu \mathrm{S} / \mathrm{sm}$, and is polluted with ammonium. Khunjil River is characterized as hydrocarbonate type with total anions and cations of_153.2 mg/dm ${ }^{3}$, hardness of

Table 2. Ions in Ider and Khujil Rivers

\begin{tabular}{|c|c|c|c|c|c|c|c|}
\hline \multicolumn{8}{|c|}{ Upstream of Ider River (N 48 $36^{\prime} 04.1^{\prime \prime}$, E $99^{\circ} 21^{\prime} 01.1 ", 1541 \mathrm{~m}$ ) } \\
\hline \multirow{2}{*}{ Anions } & \multicolumn{3}{|c|}{ In $1 \mathrm{dm}^{3}$} & \multirow{2}{*}{ Cations } & \multicolumn{3}{|c|}{$\mathrm{In} 1 \mathrm{dm}^{3}$} \\
\hline & $\mathrm{mg}$ & mg-eqv & mg-eqv $(\%)$ & & $\mathrm{mg}$ & mg-eqv & mg-eqv $(\%)$ \\
\hline $\mathrm{Cl}^{-}$ & 32.0 & 0.90 & 36.93 & $\mathrm{Na}^{+}+\mathrm{K}^{+}$ & 16.4 & 0.71 & 29.33 \\
\hline $\mathrm{SO}_{4}^{-2}$ & 1.0 & 0.02 & 0.85 & $\mathrm{Ca}^{+2}$ & 26.1 & 1.30 & 53.35 \\
\hline $\mathrm{NO}_{2}^{-}$ & 0.00 & 0.00 & 0.00 & $\mathrm{Mg}^{+2}$ & 4.9 & 0.40 & 16.41 \\
\hline $\mathrm{NO}_{3}^{-}$ & 1.0 & 0.02 & 0.66 & $\mathrm{NH}_{4}^{+}$ & 0.4 & 0.02 & 0.91 \\
\hline $\mathrm{CO}_{3}^{-2}$ & 0.0 & 0.00 & 0.00 & $\mathrm{Fe}^{+2}$ & 0.0 & 0.00 & 0.00 \\
\hline $\mathrm{HCO}_{3}{ }^{-}$ & 91.5 & 1.50 & 61.55 & $\mathrm{Fe}^{+3}$ & 0.0 & 0.00 & 0.00 \\
\hline Total & 125.5 & 2.44 & 100.00 & Total & 47.8 & 2.44 & 100.00 \\
\hline \multicolumn{8}{|c|}{ Khunjil River (N 483'ㄹ' $\left.20.2^{\prime \prime}, \mathrm{E} 99^{\circ} 21^{\prime} 23.1^{\prime \prime}, 1546 \mathrm{~m}\right)$} \\
\hline \multirow{2}{*}{ Anions } & \multicolumn{3}{|c|}{ In $1 \mathrm{dm}^{3}$} & \multirow{2}{*}{ Cations } & \multicolumn{3}{|c|}{ In $1 \mathrm{dm}^{3}$} \\
\hline & $\mathrm{mg}$ & mg-eqv & mg-eqv (\%) & & $\mathrm{mg}$ & mg-eqv & mg-eqv (\%) \\
\hline $\mathrm{Cl}^{-}$ & 14.9 & 0.42 & 20.55 & $\mathrm{Na}^{+}+\mathrm{K}^{+}$ & 14.3 & 0.62 & 30.40 \\
\hline $\mathrm{SO}_{4}^{-2}$ & 0.5 & 0.01 & 0.51 & $\mathrm{Ca}^{+2}$ & 20.0 & 1.00 & 48.94 \\
\hline $\mathrm{NO}_{2}^{-}$ & 0.00 & 0.00 & 0.00 & $\mathrm{Mg}^{+2}$ & 4.9 & 0.40 & 19.58 \\
\hline $\mathrm{NO}_{3}^{-}$ & 0.8 & 0.01 & 0.63 & $\mathrm{NH}_{4}^{+}$ & 0.4 & 0.02 & 1.09 \\
\hline $\mathrm{CO}_{3}^{-2}$ & 0.0 & 0.00 & 0.00 & $\mathrm{Fe}^{+2}$ & 0.0 & 0.00 & 0.00 \\
\hline $\mathrm{HCO}_{3}{ }^{-}$ & 97.6 & 1.60 & 78.30 & $\mathrm{Fe}^{+3}$ & 0.0 & 0.00 & 0.00 \\
\hline Total & 113.8 & 2.04 & 100.00 & Total & 39.6 & 2.04 & 100.00 \\
\hline \multicolumn{8}{|c|}{ Downstream of Ider River (N 48³5'27.1", E 99º'19'28.3", 1544 m ) } \\
\hline \multirow{2}{*}{ Anions } & \multicolumn{3}{|c|}{ In $1 \mathrm{dm}^{3}$} & \multirow{2}{*}{ Cations } & \multicolumn{3}{|c|}{$\mathrm{In} 1 \mathrm{dm}^{3}$} \\
\hline & $\mathrm{mg}$ & mg-eqv & mg-eqv (\%) & & $\mathrm{mg}$ & mg-eqv & mg-eqv (\%) \\
\hline $\mathrm{Cl}^{-}$ & 14.2 & 0.40 & 17.22 & $\mathrm{Na}^{+}+\mathrm{K}^{+}$ & 7.8 & 0.34 & 14.61 \\
\hline $\mathrm{SO}_{4}{ }^{-2}$ & 0.3 & 0.01 & 0.27 & $\mathrm{Ca}^{+2}$ & 28.1 & 1.40 & 60.28 \\
\hline $\mathrm{NO}_{2}^{-}$ & 0.01 & 0.00 & 0.01 & $\mathrm{Mg}^{+2}$ & 6.1 & 0.50 & 21.53 \\
\hline $\mathrm{NO}_{3}^{-}$ & 1.0 & 0.02 & 0.69 & $\mathrm{NH}_{4}^{+}$ & 1.5 & 0.08 & 3.59 \\
\hline $\mathrm{CO}_{3}{ }^{-2}$ & 0.0 & 0.00 & 0.00 & $\mathrm{Fe}^{+2}$ & 0.0 & 0.00 & 0.00 \\
\hline $\mathrm{HCO}_{3}{ }^{-}$ & 115.9 & 1.90 & 81.80 & $\mathrm{Fe}^{+3}$ & 0.0 & 0.00 & 0.00 \\
\hline Total & 131.4 & 2.32 & 100.00 & Total & 43.4 & 2.32 & 100.00 \\
\hline
\end{tabular}


$1.4 \mathrm{mg}$-eqv $/ \mathrm{dm}^{3}, \mathrm{pH}$ of 7.97 , oxidation of 3.36 $\mathrm{mg} / \mathrm{dm}^{3}$ and electric conductivity of $136 \mu \mathrm{S} / \mathrm{sm}$, and is polluted with azane. Downstream of Ider River is characterized as hydrocarbonate with total anions and cations of $175.3 \mathrm{mg} / \mathrm{dm}^{3}$, hardness of $1.9 \mathrm{mg}$-eqv/ $/ \mathrm{dm}^{3}, \mathrm{pH}$ of 7.9 , oxidation of $2.2 \mathrm{mg} / \mathrm{dm}^{3}$ and electric conductivity of $136 \mu \mathrm{S} / \mathrm{sm}$, and is highly polluted with ammonium.

Table 2 shows that only $\mathrm{HCO}_{3}{ }^{-2}$ in upstream of Ider River is lower than that of Khunjil River although all anions in upstream of Ider River is higher than those in Khunjil River. $\mathrm{NO}_{3}{ }^{-}$and $\mathrm{HCO}_{3}{ }^{-2}$ in downstream of Ider River are higher than those in upstream of Ider River and Khunjil River. All cations in upstream of Ider River is higher than those in Khunjil River (Table 2). Meanwhile $\mathrm{Ca}^{+2}, \mathrm{Mg}^{+2}$ and $\mathrm{NH}_{4}{ }^{+}$in downstream of Ider River are higher than those in upstream of Ider River and Khunjil River. Hardness in upstream of Ider River is higher than those in downstream of Ider River and Khunjil River. Oxidation of Khunjil River is greater than that of Ider River. The upstream and downstream of Ider River are polluted with $\mathrm{NH}_{4}{ }^{+}$, while Khunjil River is polluted with $\mathrm{NH}_{3}^{+}$. Our results from ion concentration in runoff of Ider River are hydrogeochemically coincided with that by Tsegmid (1969) noted that Ider River is a hydrocarbonate and calcium type with ranging in $\mathrm{pH}$ from 6.2 to 7.0 although it is smoothly alkalised.

Groundwater is temporarily protected from runoff and transportation of materials and pollutants. However in addition to that human activity such as mining (e.g., oil drilling, ore

Table 3. Ions in groundwaters in valley of the Ider

\begin{tabular}{|c|c|c|c|c|c|c|c|}
\hline \multicolumn{8}{|c|}{ Groundwater in school (N 48³5'1.13", E 99²0'59.15", $1560 \mathrm{~m}$ ) } \\
\hline \multirow{2}{*}{ Anions } & \multicolumn{3}{|c|}{ In $1 \mathrm{dm}^{3}$} & \multirow{2}{*}{ Cations } & \multicolumn{3}{|c|}{ In $1 \mathrm{dm}^{3}$} \\
\hline & $\mathrm{mg}$ & mg-eqv & mg-eqv (\%) & & $\mathrm{mg}$ & mg-eqv & mg-eqv $(\%)$ \\
\hline $\mathrm{Cl}^{-}$ & 3.6 & 0.10 & 3.09 & $\mathrm{Na}^{+}+\mathrm{K}^{+}$ & 4.8 & 0.21 & 6.51 \\
\hline $\mathrm{SO}_{4}{ }^{-2}$ & 20.0 & 0.42 & 12.89 & $\mathrm{Ca}^{+2}$ & 42.1 & 2.10 & 64.96 \\
\hline $\mathrm{NO}_{2}^{-}$ & 0.00 & 0.00 & 0.00 & $\mathrm{Mg}^{+2}$ & 10.9 & 0.90 & 27.84 \\
\hline $\mathrm{NO}_{3}{ }^{-}$ & 1.0 & 0.02 & 0.50 & $\mathrm{NH}_{4}^{+}$ & 0.4 & 0.02 & 0.69 \\
\hline $\mathrm{CO}_{3}^{-2}$ & 0.0 & 0.00 & 0.00 & $\mathrm{Fe}^{+2}$ & 0.0 & 0.00 & 0.00 \\
\hline $\mathrm{HCO}_{3}{ }^{-}$ & 164.7 & 2.70 & 83.52 & $\mathrm{Fe}^{+3}$ & 0.0 & 0.00 & 0.00 \\
\hline Total & 189.3 & 3.23 & 100.00 & Total & 58.3 & 3.23 & 100.00 \\
\hline \multicolumn{8}{|c|}{ Groundwater in center of Jargalant soum (N 48³4'54.82", E 99 $\left.21^{\circ} 1^{\prime} 8.28^{\prime \prime}, 1561 \mathrm{~m}\right)$} \\
\hline \multirow{2}{*}{ Anions } & \multicolumn{3}{|c|}{ In $1 \mathrm{dm}^{3}$} & \multirow{2}{*}{ Cations } & \multicolumn{3}{|c|}{ In $1 \mathrm{dm}^{3}$} \\
\hline & $\mathrm{mg}$ & mg-eqv & mg-eqv (\%) & & $\mathrm{mg}$ & mg-eqv & mg-eqv (\%) \\
\hline $\mathrm{Cl}^{-}$ & 21.3 & 0.60 & 13.13 & $\mathrm{Na}^{+}+\mathrm{K}^{+}$ & 14.9 & 0.65 & 14.16 \\
\hline $\mathrm{SO}_{4}{ }^{-2}$ & 1.0 & 0.02 & 0.46 & $\mathrm{Ca}^{+2}$ & 50.1 & 2.50 & 54.71 \\
\hline $\mathrm{NO}_{2}^{-}$ & 0.01 & 0.00 & 0.00 & $\mathrm{Mg}^{+2}$ & 17.0 & 1.40 & 30.64 \\
\hline $\mathrm{NO}_{3}{ }^{-}$ & 3.0 & 0.05 & 1.06 & $\mathrm{NH}_{4}^{+}$ & 0.4 & 0.02 & 0.49 \\
\hline $\mathrm{CO}_{3}^{-2}$ & 0.0 & 0.00 & 0.00 & $\mathrm{Fe}^{+2}$ & 0.0 & 0.00 & 0.00 \\
\hline $\mathrm{HCO}_{3}{ }^{-}$ & 237.9 & 3.90 & 85.35 & $\mathrm{Fe}^{+3}$ & 0.0 & 0.00 & 0.00 \\
\hline Total & 263.2 & 4.57 & 100.00 & Total & 82.4 & 4.57 & 100.00 \\
\hline \multicolumn{8}{|c|}{ 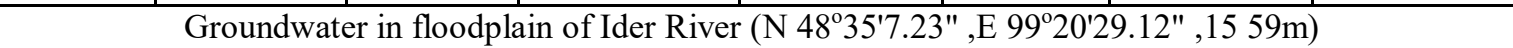 } \\
\hline \multirow{2}{*}{ Anions } & \multicolumn{3}{|c|}{ In $1 \mathrm{dm}^{3}$} & \multirow{2}{*}{ Cations } & \multicolumn{3}{|c|}{ In $1 \mathrm{dm}^{3}$} \\
\hline & $\mathrm{mg}$ & mg-eqv & mg-eqv (\%) & & $\mathrm{mg}$ & mg-eqv & mg-eqv $(\%)$ \\
\hline $\mathrm{Cl}^{-}$ & 21.3 & 0.60 & 10.58 & $\mathrm{Na}^{+}+\mathrm{K}^{+}$ & 15.7 & 0.68 & 12.00 \\
\hline $\mathrm{SO}_{4}^{-2}$ & 25.0 & 0.52 & 9.19 & $\mathrm{Ca}^{+2}$ & 57.1 & 2.85 & 50.27 \\
\hline $\mathrm{NO}_{2}{ }^{-}$ & 0.01 & 0.00 & 0.00 & $\mathrm{Mg}^{+2}$ & 25.5 & 2.10 & 37.04 \\
\hline $\mathrm{NO}_{3}{ }^{-}$ & 3.0 & 0.05 & 0.85 & $\mathrm{NH}_{4}^{+}$ & 0.7 & 0.04 & 0.69 \\
\hline $\mathrm{CO}_{3}{ }^{-2}$ & 0.0 & 0.00 & 0.00 & $\mathrm{Fe}^{+2}$ & 0.0 & 0.00 & 0.00 \\
\hline $\mathrm{HCO}_{3}{ }^{-}$ & 274.5 & 4.50 & 79.37 & $\mathrm{Fe}^{+3}$ & 0.0 & 0.00 & 0.00 \\
\hline Total & 323.8 & 5.67 & 100.00 & Total & 99.0 & 5.67 & 100.00 \\
\hline
\end{tabular}


operation, etc.), agriculture and solid wastes strongly impact on groundwater level, infiltration of chemicals by runoff and capillary action through soil profiles influences in the groundwater composition. Because flow rate of groundwater running through bedrocks is lower than that of runoff, pollution of groundwater depends on infiltration through soils and bedrocks (Dorj et al., 2005).

Table 3 shows hydrogeochemical results from groundwater in valley of the Ider River along Jargalant soum, Khuvsgul aimag. Groundwater in school is characterised as hydrocarbonate with total anions and cations of $247.5 \mathrm{mg} / \mathrm{dm}^{3}$, hardness of $3.0 \mathrm{mg}$-eqv/ $/ \mathrm{dm}^{3}, \mathrm{pH}$ of 7.56 , oxidation of $4.8 \mathrm{mg} / \mathrm{dm}^{3}$ and electric conductivity of $346 \mu \mathrm{S} / \mathrm{sm}$, and is polluted with ammonium. It is coincided with national standard level of drinking water (MNS 900:2010). Groundwater in center of Jargalant soum is characterised as hydrocarbonate with total anions and cations of $345.6 \mathrm{mg} / \mathrm{dm}^{3}$, hardness of $3.9 \mathrm{mg}$-eqv $/ \mathrm{dm}^{3}, \mathrm{pH}$ of 7.56 , oxidation of $1.28 \mathrm{mg} / \mathrm{dm}^{3}$ and electric conductivity of $310 \mu \mathrm{S} / \mathrm{sm}$, and is polluted with ammonium. It is also coincided with national standard level of drinking water (MNS 900:2010). Groundwater of well locating at 600 $\mathrm{m}$ away from channel of Ider River is characterized as hydrocarbonate with total anions and cations of $422.8 \mathrm{mg} / \mathrm{dm}^{3}$, hardness of $4.95 \mathrm{mg}$-eqv $/ \mathrm{dm}^{3}, \mathrm{pH}$ of 7.59 , oxidation of 0.8 $\mathrm{mg} / \mathrm{dm}^{3}$ and electric conductivity of $461 \mu \mathrm{S} / \mathrm{sm}$, and is polluted with ammonium. It is coincided with national standard level of drinking water (MNS 900:2010).

Anions of groundwater in school is more enriched with $\mathrm{SO}_{4}^{-2}$ than those in center of Jargalant soum and floodplain of Ider River (Table 3). Groundwater in center of Jargalant soum is highly enriched with $\mathrm{Cl}^{-}$and $\mathrm{NO}_{3}^{-}$than those in school and floodplain of Ider River. Groundwater in floodplain is higher with $\mathrm{HCO}_{3}{ }_{3}$. Cations in groundwater in center of Jargalant soum is enriched with $\mathrm{Na}^{+}+\mathrm{K}^{+}$, while groundwater in floodplain is higher with $\mathrm{Ca}^{+2}$, $\mathrm{Mg}^{+2}$ and $\mathrm{NH}_{4}^{+}$than those in groundwater in school and center of Jargalant soum.

Generally, Ider River and groundwater in valley of the Ider River are comparable with their anions and cations. Ider River is highly polluted with an anion of $\mathrm{Cl}^{-}$in 2-3 times, cations of $\mathrm{Na}^{+}+\mathrm{K}^{+}$in 2-3 times and $\mathrm{NH}_{4}^{+}$in 0.5-1.0 times than its groundwater although hardness and electric conductivity are higher in groundwater than those in Ider River. Table 4 shows our hydrogeochemical results from Ider River coincides with previous study by Davaa (2015) except for the anions of $\mathrm{SO}_{4}{ }^{-2}$ and $\mathrm{Cl}^{-}$.

Table 4. Ion components in Ider River

\begin{tabular}{lllllll}
\hline Ions (mg/l) & $\mathrm{Ca}^{+2}$ & $\mathrm{Mg}^{+2}$ & $\mathrm{Na}^{+}+\mathrm{K}^{+}$ & $\mathrm{HCO}_{3}^{-}$ & $\mathrm{SO}_{4}^{-2}$ & $\mathrm{Cl}$ \\
\hline Ider River (Davaa, 2015) & 22.94 & 6.46 & 13.95 & 101 & 16.56 & 5.57 \\
Ider River (This study) & 26.1 & 4.9 & 16.4 & 91.5 & 1.0 & 32.0 \\
\hline
\end{tabular}

\section{DISCUSSION}

Hydrogeochemical data reveal that the water of Ider River is more influenced by anthropogenic activities including over exploitation by local people and tourists. This fits with that the Integrated Water Management Plan (IWMP) by the Ministry of Environment and Green Development (2013) showing that the most important key factors for determining the water demands are population, municipal services, industries, mines and energy productions, agriculture, tourism and environment.
Groundwater in the cathment of Ider River is characterized by ions. The main contributor of $\mathrm{Ca}^{2+}, \mathrm{Mg}^{2+}$ and $\mathrm{HCO} 3$ ions to the groundwater on Rameswaram Island was carbonate weathering process (Kumar et al., 2012).

\section{CONCLUSIONS}

This study shows that hydrogeochemical characteristics of Ider River and groundwater in its valley are spatially clarified in northern Mongolia. It indicates 
that runoff and groundwater are hydrogeochemically estimated with hydrocarbonate type. The upstream of Ider River and Khunjil River draining into the Ider River have more freshwater in comparison with downstream of Ider River enriched with $\mathrm{NH}_{4}{ }^{+}$. Runoff is highlighted by $\mathrm{N}^{+}+\mathrm{K}^{+}, \mathrm{NH}_{4}{ }^{+}$and $\mathrm{Cl}^{-}$ than those in groundwater. The changing trends in the hydrogeochemical components in the downstream of Ider River show the more influence by solid wastes along the settlement areas such as Ider, Tosontsengel, Ikh Uul and Jargalant soums than natural processes influencing water regime of Ider River linked with local geomorphic feature and climatic conditions in the Ider River basin. Hydrogeochemical controls on runoff and groundwater of large rivers are necessary for a more complete understanding of the hydrological evolution in drainage basins in Mongolia.

\section{REFERENCES}

Amgalan-Erdene, N. 2014. Solid waste management of Jargalant Soum, Khuvsgul. Ulaanbaatar. Master Thesis. p. 65.

Bolorchimeg, Sh. 2013. Reflecting experience of Japan to improve management of solid waste in Ulaanbaatar. Ulaanbaatar. p. 60.

Dashdeleg, D. 1970. Rivers of Mongolia. Ulaanbaatar.

Davaa, G. 2015. Regime and resource of surface water of Mongolia. Ulaanbaatar. p. 408.

Dorj, D., Davaasuren, S., Darjaa, Ts. 2005. Environmental chemical analysis Ulaanbaatar. p. 261.

Jargalant Meteorological Station. Khuvsgul. 2009-2013.

Karthe, D. 2018. Environmental Changes in Central and East Asian Drylands and their Effects on Major River-Lake Systems.
Quaternary International 475. 91-100.

Kumar, S. K., Chandrasekar, N., Seralathan, P., Godson, P. S., Magesh, N. S. 2012. Hydrogeochemical study of shallow carbonate aquifers, Rameswaram Island, India Environmental Monitoring and Assessment. $184 \quad$ (7). 4127-4138. doi:10.1007/s10661-011-2249-6.

Mitrophanov P.F., Kozakov I.K., Falei I.F. 1981. Precambrian western Mongolia and Southern Tuva. Scientific research report of Russian-Mongolian joint geological expedition. "Nauka," Leningrad, 156 pp (in Russian).

Ministry of Environment and Green Development, 2013, Integrated Water Management Plan: Mongolia. Ulaanbaatar. p. 341.

Ministry of Nature and Environment. 2004. Solid waste management of settlements in Ulaanbaatar. p. 106.

National Atlas of Mongolia. 2009. Ulaanbaatar. p. 144.

Orkhonselenge, A., Harbor, J.M. 2018. Impacts of Modern Glacier Changes on Surface Water Resources in Western and Northern Mongolia. Journal of Water Resource and Protection 10(6). 559-576.

Sanjmyatav, Z. 2007. Physical Geography of Mongolia. Ulaanbaatar. p. 204.

Tsegmid, Sh. 1969. Physical Geography of Mongolia. Ulaanbaatar. p. 405.

Wu, P., Tang, C., Zhu, L., Liu, C., Cha, X., Tao, X. 2009. Hydrogeochemical characteristics of surface water and groundwater in the karst basin, southwest China. John Wiley \& Sons, Ltd. Hydrological Processes 23 (14). 20122022. 